\title{
Amputációk a kéz sérüléseiben
}

\author{
DR. RENNER ANTAL, DR. SZENTIRMAI ANNAMÁRIA
}

\section{ÖSSZEFOGLALÁS}

A Baleseti Központban 5 évre terjedő amputációs kéz- és felső végtag sérültek ellátási dokumentációjának retrospektív feldolgozása: a primer csonkolások, rekonstrukciók, revaszkularizációk, replantációk számarányainak elemzése, és a saját adatok összehasonlítása a nemzetközi irodalom közléseivel. Megállapítható, hogy bár a replantációk finanszírozása mindenütt veszteséges, külföldön ennek ellenére számuk nem csökkent, sőt jelentősen több mint a saját anyagban, továbbá a sebészi technika fejlődése már lehetővé teszi a körömpercek distalis amputátumainak eredményes replantációját is. A vizsgált időszakban megkísérelt 4 replantáció sikertelen volt, amelynek egyik lehetséges oka a lupéval, s nem mikroszkóppal végzett mútét. További figyelemre érdemes, hogy a sikertelen 4 replantációból 3 gyermeknél történt, ugyanakkor 5 alkalommal sikeres revaszkularizációt végeztek 43/52/52/64/66 éves sérültnél. A csonkolások az esetek 2/3-ában jelentősebb rövidítéssel történtek, a sérüléses amputációs szint megtartása csak ritkán fordult elő, mindössze négyszer alkalmaztak a csonk hosszát megtartó mútéti technikát. Figyelmet érdemlő adat a betegfelvételtől a mútétig eltel idő, amely az esetek egy negyedében $(24,5 \%) 6$ óránál több volt, ezen belül 12\%-ban 8 óránál is hosszabb, amelynek egyik lehetséges oka az időigényes mikrosebészeti mútétnek nem kedvező múszakos munkarend, és a csökkentett létszámú ügyeleti csapat lehet.

\section{Kulcsszavak: $\quad$ Amputáció; Kézsérülés; Rekonstruktiv sebészet; Replantáció; Statisztikai adatok;}

\section{A. Renner, A. Szentirmai: Amputations after hand injuries}

Retrospective evaluation of patient documentation after hand and upper limb amputations performed at Péterfy Hospital, Trauma Centre during a period of five years: analysis of the numbers of primary resections, reconstructions, revascularisations and replantations, compared to those published in the international literature. We ascertained that financing of replantations is disadvantageous everywhere; however, despite of this fact, the number of replantations didn't decrease abroad and is much higher than among our patients. Furthermore, the evolution of surgical technique allows a successful replantation also after amputation of the distal section of the terminal phalanx. There were 4 unsuccessful replantations in the investigated period; a possible reason for that may be the surgery performed with a magnifying glass instead of a microscope. It is remarkable that 3 out of 4 unsuccessful replantations were performed on children and 5 successful revascularisations were performed on 43/52/52/64/66 year old patients. Resections resulted in $2 / 3$ of the cases in considerable shortening; the level of the amputation caused by injury could be preserved only in 4 cases. The time elapsed between patient admission to surgery is a remarkably important factor; it was longer than 6 hours in $24.5 \%$ of the cases and more than 8 hours in $12 \%$ of the cases. Possible reasons for that may be working in relays and the reduced number of the staff: these are not advantageous for time-consuming microsurgical interventions.

\section{Key words: $\quad$ Amputation, traumatic - Statistics and numerical data; Hand - Surgery; Replantation - Statistics and numerical data; Reconstructive surgical procedures;}




\section{ELÖZMÉNYEK}

Több mint egy évtizedig voltam Szaklapunknak - a Magyar Traumatológia Ortopédia Kézsebészet Plasztikai Sebészet - a főszerkesztője, s e tisztséget 2014-ben Dr. Fekete Károly professzor úrnak átadva, késztetést éreztem egyfajta összegzés elkészítésére, hogy e feladatom időszakában, mely témákban jelentek meg közlemények, s milyen arányban gazdagították olvasóink ismereteit a négy szakterület kórházi, klinikai intézményei.

A kézsebészeti téma szerkesztőjeként megdöbbenéssel tapasztaltam, hogy a korábban Európában a legjobbak között rangsorolt hazai kézsebészet egyik legértékesebb műtéti eljárásáról, a mikrosebészeti lehetőségekről, egyetlen írásos anyag sem szerepelt, sőt nem egyszer hallottam, hogy a kéz sérüléseinek kezelésében az amputáció egy „elfelejtett jó mútét"...!

E tények adták az ötletet, hogy hazánk legnagyobb traumatológiai intézményében - a Péterfy Sándor Utcai Kórház-Rendelőintézet és Baleseti Központjában - feldolgozzuk az elmúlt 5 év amputációs sérültjeinek ellátását, a definitív kezelés módszereit, különös tekintettel a mikrosebészeti eljárásokra, $s$ az eredményt összehasonlítsuk a nemzetközi irodalom adataival.

\section{BEVEZETÉS}

A Baleseti Központban 5 évre terjedő retrospektív elemzést végeztünk, a kézsérülteknél és a felső végtagon történt amputációk anyagát tekintettük át. Elemeztük a traumás amputáció és a végső sebészi csonkolás magasságát, a csonkfedés sebészi technikáját, a revaszkularizáció és a replantáció számarányait, végül, az ellátást hogyan befolyásolta a sérülést ellátó orvosok szakmai felkészültsége, illetve egyéb objektív tényezők. Az amputációk helyét Tamai beosztása szerint osztályoztuk. Elemzésünk eredményeit összehasonlítottuk a nemzetközi irodalomban megjelent közlemények adataival. A vizsgálatunkat három részre bontva közöljük. Jelen, első dolgozatunkban a statisztikai adatok elemzését és az ezekből levont következtetéseinket ismertetjük. A 2 . számú publikációban fogjuk bemutatni azokat a mútéteket, a!nelyekke! a csonì képzés és a csonk fedése a sérüléses szint további jelentősebb rövidítése nélkül elvégezhető. A 3. számú dolgozatban tervezzük közzétenni azokat a fogásképesség helyreállítására végezhető mútéteket, amelyek súlyosabb esetekben a beteg életét megkönnyítő fogásképesség kialakítását biztosítják.

\section{BETEGANYAG ÉS MÓDSZER}

A Baleseti Központban 2009. június 1. és 2014. június 1 . között -5 év alatt - 155 kézés felső végtag sérültnél 157 végtagon történt amputációs sérülés. E betegek kórlapjainak és képalkotó dokumentációjának feldolgozását végeztük, az ebből nyert adatokat elemeztük és összevetettük a nemzetközi irodalom publikációinak adataival.

A sérülések szintjét a kórlapban leírt status és a primer röntgenfelvétel alapján, a csonkolás végső magasságát a mútéti leírás és a posztoperatív röntgenfelvétel alapján határoztuk meg. Az amputáció szintjének besorolásához Tamai osztályozását használtuk (1. ábra).

Külön értékeltük azt a 4 beteget, akiknél a felső végtagon makro-amputáció fordult elő (I. táblázat). Rekonstrukciónak tekintettük az érvarrat nélküli amputatum „visszavarrást”, a csontegyesítő tűzést, primer desist, az ín- és idegvarratok végzését. 


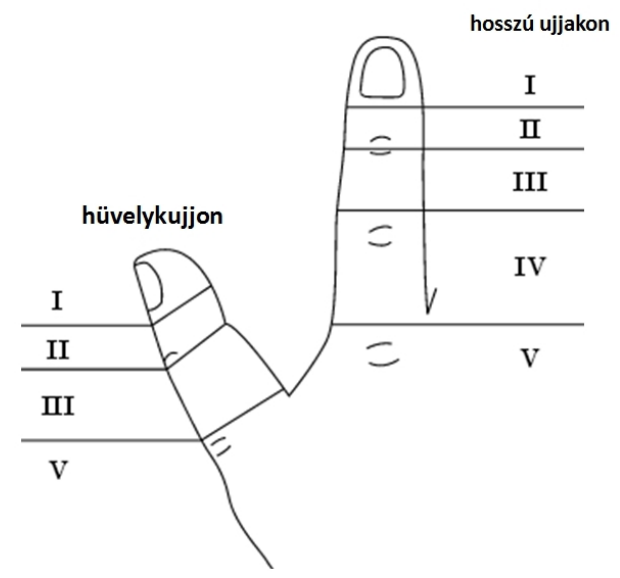

1. ábra Amputációk osztályozása Tamai szerint I. distalisan a FDP tapadásától

II. DIP ízület a FDP tapadásáig

III. középperc distalisan a FDS tapadásától

IV. alapperc és középperc a FDS tapadásáig

V. MCP ízület és ettöl proximalisan

\section{I. táblázat Makro-amputációk}

\begin{tabular}{|c|c|c|c|}
\hline Sérülés szintje & Sérülés oka & 2012 & 2013 \\
\hline $\begin{array}{c}\text { jobb könyök IV fokban nyílt } \\
\text { törése }\end{array}$ & $\begin{array}{c}\text { liftszerelésnél a lift } \\
\text { rázuhant }\end{array}$ & 1 & \\
\hline $\begin{array}{c}\text { bal kéz } \\
\text { radiocarpalis ízület }\end{array}$ & autó utas & 1 & \\
\hline $\begin{array}{c}\text { bal humerus distalis vég, } \\
\text { könyök II fokban } \\
\text { nyílt törése }\end{array}$ & motorkerékpár vezető & & 1 \\
\hline $\begin{array}{c}\text { bal humerus } \\
\text { proximalis harmadban } \\
\text { Összesen: } 4 \text { beteg }\end{array}$ & autó utas & & \\
\hline
\end{tabular}




\section{EREDMÉNYEK}

\section{A sérültek életkor szerinti megoszlása}

Meglepően magasnak találtuk a 10 év alatti gyerekek számát, s mind a férfi, mind a nőbetegeknél a munkaképes életkor dominált (2. ábra).

\section{A sérülés helyszíne és a beszállitás módja}

Feltűnően magas az otthon elszenvedett sérülések száma. Ezek a lakásban és a ház körül végzett gépesített szerelések, javítások, szabadidős tevékenységek, barkácsolás következményei. Meglepően sok kórlapban (26,5\%) azonban nem találtunk utalást a sérülés helyszínére. A sérültek 44,5\%-át mentő szállította, a többiek egyéb módon érkeztek (II. táblázat). $\mathrm{Az}$ összes sérült $25 \%$-a járt előzetesen szakrendelőben, más kórházban, ambulancián, ahonnan elsősegély után irányították a Baleseti Központba. Ezen sérültek közül azoknál, ahol totális amputóció törtérit, aź cimputatumat minden esetben szabályosan csomagolva szállították!

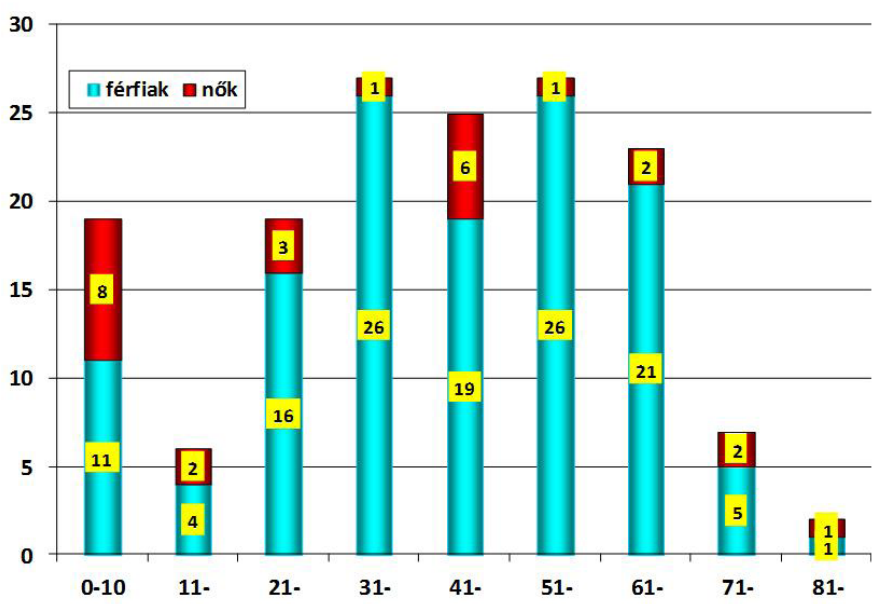

2. ábra Életkor szerinti megoszlás

\section{II. táblázat A sérülés helyszíne, a beszállítás módja, a beutaló intézmények típusa}

\begin{tabular}{|l|c|l|l|}
\hline Sérülés helyszíne & & Beszállítás módja & \\
\hline otthon & $65(42 \%)$ & mentővel & $69(44,5 \%)$ \\
\hline munkahely & $31(20 \%)$ & egyéb & $86(55,5 \%)$ \\
\hline közlekedés & $9(6 \%)$ & Beutaló intézmény & \\
\hline közterület & $5(3 \%)$ & szakrendelő & 12 \\
\hline sport & $4(2,5 \%)$ & kórház & 13 \\
\hline nincs adat (!) & $41(26,5 \%)$ & BK JBA & 14 \\
\hline & & Összesen & $\mathbf{3 9}(\mathbf{2 5} \%)$ \\
\hline
\end{tabular}




\section{A betegfelvétel időpontja}

A betegek 4/5-e (83\%) nappal érkezett, $29 \%$ délelőtt, $54 \%$ délután. 19.00 óra és reggel 07.00 óra között 17\% (III. táblázat).

$\mathrm{Az}$ elemzés során sajnálatos hiányosságokat tapasztaltunk. A kórlapokból alig néhány esetben lehetett megállapítani a sérülés időpontját, pedig egy esetleges replantációnál az időfaktor nagyon fontos tényező! A leggyakoribb megfogalmazások a „beszállítása előtt” vagy „a mai napon” voltak. Ugyancsak hiányzik annak rögzítése a kórlapban, hogy melyik a beteg domináns keze? Holott ez is alapvető szempont a mútéti indikáció eldöntésénél! Mindössze 3 sérült foglalkozása volt kideríthető.

\section{A sérülés módja}

Igen fontos szempont, mert utal a sérülés szennyezettségi fokára, kompressziós sérüléseknél a sérült ujj és az egész kéz keringésére. Anyagunkban a sérülések $72,3 \%$-át valamiIyen roncsoló gép okozta, gyermekeknél gyakori volt ajtó/két tárgy okozta „becsípődés” (IV. táblázat).

\section{III. táblázat A betegfelvétel idöpontja}

\begin{tabular}{|c|c|c|c|c|c|c|c|c|}
\hline & 2009 & 2010 & 2011 & 2012 & 2013 & 2014 & \multicolumn{2}{|c|}{ Összesen } \\
\hline délelőtt & 4 & 11 & 10 & 10 & 8 & 2 & $\begin{array}{c}45 \\
(29 \%)\end{array}$ & $\begin{array}{c}128 \\
(83 \%)\end{array}$ \\
\hline délután & 16 & 18 & 14 & 6 & 20 & 9 & $\begin{array}{c}83 \\
(54 \%)\end{array}$ \\
\hline este/éjjel & 2 & 12 & 5 & 5 & 2 & 1 & $27(17 \%)$ \\
\hline Összesen & 22 & 41 & 29 & 21 & 30 & 12 & 155 \\
\hline
\end{tabular}

\section{IV. táblázat A sérülés módja}

\begin{tabular}{|c|c|c|c|c|c|}
\hline körfürész & & 36 & \multirow[b]{4}{*}{64} & \multirow{2}{*}{$\begin{array}{l}\text { becsípődés } \\
\text { állati harapás }\end{array}$} & 13 \\
\hline fürész/fürészgép & $3 / 6$ & 9 & & & 4 \\
\hline marógép/gyalugép & $8 / 1$ & 9 & & gyürúsérülés & 2 \\
\hline flex & & 10 & & közlekedés & 7 \\
\hline darálógép/törőgép & $5 / 1$ & 6 & & ékszíj/kerékpárlánc & 3 \\
\hline húsdaráló & & 4 & & verekedés & 1 \\
\hline betonkeverő/betonpum & $2 / 2$ & 4 & & kalapács & 2 \\
\hline fünyíró & & 10 & 24 & nincs adat & 2 \\
\hline $\begin{array}{l}\text { kompressziós sérülés } \\
\text { nehéz tárgy ráesett } \\
\text { két tárgy közé szorult } \\
\text { két henger közé szorult } \\
\text { présgép }\end{array}$ & $\begin{array}{l}8 \\
5 \\
2 \\
9\end{array}$ & 24 & 24 & \begin{tabular}{ll}
\multicolumn{2}{c}{ éles tárgy } \\
üveg/vaslap & 3 \\
balta & 6
\end{tabular} & 9 \\
\hline összesen & & & $\begin{array}{c}112 \\
(72,3 \%)\end{array}$ & & $\begin{array}{c}43 \\
(27,7 \%)\end{array}$ \\
\hline
\end{tabular}


A kórházi felvételtöl a mútétig eltelt idő, és a mütétek időtartama

Mivel a sérülés pontos ideje nem szerepel a betegfelvételi adatok között, ezért nem lehetett kiszámítani a sérüléstől a mútéti ellátásig eltelt időt, csak a kórházi felvétel időpontja jelentett támpontot! Hét kórlapban nem találtunk mútéti leírást, ezek Oberst érzéstelenítésben végzett mútétek voltak. A sérültek alig több mint negyede $(26,5 \%) 3$ órán belül, közel fele (49\%) 3 órán túl, de 6 órán belül, míg közel negyede $(24,5 \%) 6$ órán túl került ellátásra. A 6 óránál hosszabb kórházi várakozás után végzett mútétek 78\%-át (!) nem abban a múszakban kezdték el, amelyikben a beteget felvették ( $V$. táblázat)!

A mútétek 2/3-ának (66\%) időtartama rövidebb volt 1 óránál, egy negyede (26\%) 1 és 2 óra közé esett, míg 8\%-a meghaladta a 2 órát (VI. táblázat).

\begin{tabular}{|c|c|c|c|c|c|c|c|}
\hline 1 óra & 1 & 3 óra & 2 & 5 óra & 5 & 8 óra & 3 \\
\hline 1 óra 20 perc & 1 & 3 óra 15 perc & 5 & 5 óra 15 perc & 3 & 8 óra 30 perc & 1 \\
\hline 1 óra 25 perc & 1 & 3 óra 30 perc & 3 & 5 óra 20 perc & 2 & 8 óra 40 perc & 1 \\
\hline 1 óra 30 perc & 7 & 3 óra 35 perc & 6 & 5 óra 30 perc & 5 & 9 óra & 3 \\
\hline 1 óra 40 perc & 3 & $\begin{array}{l}3 \text { óra } 40 \text { perc } \\
3 \text { óra } 45 \text { perc }\end{array}$ & $\begin{array}{l}3 \\
3\end{array}$ & 5 óra 35 perc & 3 & 9 óra 35 perc & 1 \\
\hline 2 óra & 11 & 4 óra & 15 & 6 óra & 6 & 10 óra 30 perc & 1 \\
\hline 2 óra 15 perc & 1 & 4 óra 15 perc & 2 & 6 óra 30 perc & 2 & 12 óra 15 perc & 2 \\
\hline 2 óra 20 perc & 2 & 4 óra 20 perc & 4 & 6 óra 35 perc & 1 & 13 óra 35 perc & 4 \\
\hline 2 óra 30 perc & 5 & 4 óra 30 perc & 7 & 6 óra 40 perc & 2 & 14 óra & 1 \\
\hline 2 óra 35 perc & 3 & 4 óra 45 perc & 4 & 7 óra & 6 & 15 óra & 1 \\
\hline 2 óra 45 perc & 4 & & & 7 óra 30 perc & 1 & & \\
\hline
\end{tabular}

\begin{tabular}{|c|c|c|c|}
\hline \begin{tabular}{l} 
VI. táblázat $\mathbf{A}$ mütét idötartama \\
\hline 10 perc
\end{tabular} \mid 2 & 1 óra 10 perc & 5 \\
\hline 15 perc & 6 & 1 óra 15 perc & 5 \\
\hline 20 perc & 17 & 1 óra 20 perc & 2 \\
\hline 25 perc & 10 & 1 óra 25 perc & 1 \\
\hline 30 perc & 30 & 1 óra 30 perc & 5 \\
\hline 35 perc & 2 & 1 óra 40 perc & 4 \\
\hline 40 perc & 14 & 2 óra & 5 \\
\hline 45 perc & 9 & 2 óra 30 perc & 4 \\
\hline 50 perc & 7 & 2 óra 35 perc & 1 \\
\hline 1 óra & 16 & 5 óra & 1 \\
\hline
\end{tabular}




\begin{tabular}{|c|c|c|c|c|c|c|c|}
\hline \multicolumn{8}{|c|}{ VII. táblázat Az érzéstelenítés módja } \\
\hline $\begin{array}{c}\text { Érzéstelenítés } \\
\text { módja }\end{array}$ & $\begin{array}{c}2009 . \\
\text { 06.01-től }\end{array}$ & 2010 & 2011 & 2012 & 2013 & $\begin{array}{c}2014 . \\
06.01 \text {-ig }\end{array}$ & Összesen \\
\hline Oberst & 7 & 6 & 7 & 3 & 8 & 1 & 32 \\
\hline IVRA & 7 & 15 & 8 & 9 & 7 & 1 & 47 \\
\hline Plexus & 2 & 7 & 2 & - & 7 & 1 & 19 \\
\hline Narcosis & 6 & 13 & 12 & 9 & 8 & 8 & 56 \\
\hline
\end{tabular}

\section{A mütétek érzéstelenitése}

Az esetek 21\%-ában Oberst, 43\%-ban IVRA vagy plexus érzéstelenítés történt, és $36 \%$ volt a narcosisban végzett mútétek aránya (VII. táblázat).

\section{A sérülések/amputációk és az elvégzett mütétek szintje Tamai szerint}

79 betegnek egy ujja sérült. Közülük 1 polytraumatizált motoros (bal gyűrűsujj kiszakításos amputációja) mindössze 11 órát élt, emiatt az adatfeldolgozás további szakaszából értelemszerúen kihagytuk, így 78 beteg adatait elemeztük. Nagyobb arányban sérült a bal kéz (42), mint a jobb kéz (36), legtöbbször a hüvelykujj (27), ezt követte a középsőujj (17) és majdnem azonos számban a mutatóujj (16). Jóval ritkábban sérült izoláltan a gyűrűsujj és a kisujj (9-9). Az I-es és II-es zónában helyezkedett el a sérülések 73\%-a, a III-as zónában 15\%, a IV-esben $10 \%$ (3. ábra).

Totalis amputáció 21 ujjon; subtotalis amputáció 43 ujjon; roncsolt lágyrészek/nyílt törés 15 ujjon fordult elő. A totalisan amputált 21 ujj közül 2 ujj replantációjának kísérlete történt, mindkettő sikertelen volt. Ebben a csoportban revaszkularizációs kísérlet nem történt.

A subtotalisan amputált 43 ujj közül 1 ujj replantációjának kísérlete történt, sikertelen eredménnyel. Egy revaszkularizáció ugyancsak sikertelen, míg 12 rekonstrukcióból 10 sikeres volt.
Roncsolt lágyrészek, illetve nyílt darabos törés miatt az esetek felében került sor amputációra, 1 revaszkularizáció sikertelen, 6 rekonstrukcióból 4 sikeres volt (VIII. táblázat, 4. a-c ábra).

72 betegnek több ujja (189) sérült. Totalis amputáció 56 ujjon; subtotalis amputáció 74 ujjon; roncsolt lágyrészek/nyílt törés 59 ujjon. A totalisan amputált 56 ujjon 54 amputáció, 2 rekonstrukció (ujjbegy visszavarrása gyermeknél) történt, replantáció nem volt.

A 74 subtotalisan amputált ujjon 3 sikeres revaszkularizációt és 12 sikeres rekonstrukciót találtunk.

Roncsolt lágyrészek, illetve nyílt darabos törések miatt 59 ujj közül 22 ujjon csak sebellátásra volt szükség, 31 amputáció, 1 revaszkularizáció és 5 rekonstrukció volt (X. táblázat, 5. a-c ábra).

Sem a replantációknál, sem a revaszkularizációs mútéteknél nem használtak operációs mikroszkópot, csak lupét, s nem egy esetben a lupéval mindössze egyetlen véna varratát kísérelték meg. Mind a 3 gyermeknél elvégzett replantáció sikertelen volt, a szekunder amputáció jelentős rövidítéssel, illetve a vállízületben exarticulatiós mútéttel történt. A 7 revaszkularizáció közül 5 sikeres volt, Tamai IV zónában 4, Tamai II zónában 1. A 2 sikertelen revaszkularizáció után a szekunder amputáció jelentős rövidítéssel történt (XI. $a-b$ táblázat). 


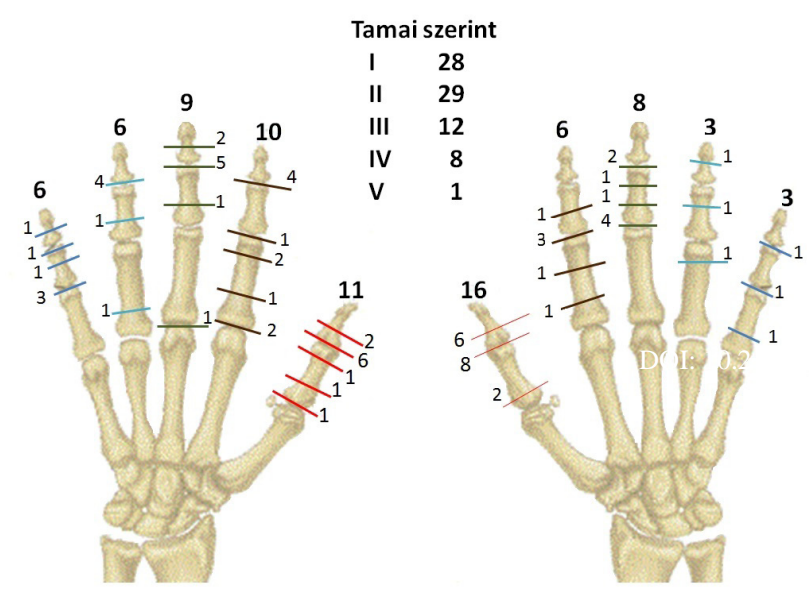

3. ábra Sérülések szintje egy ujj amputációs sérülésénél

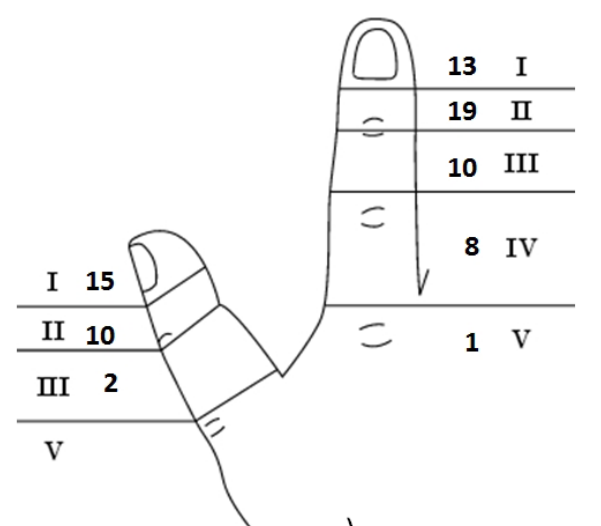

a)

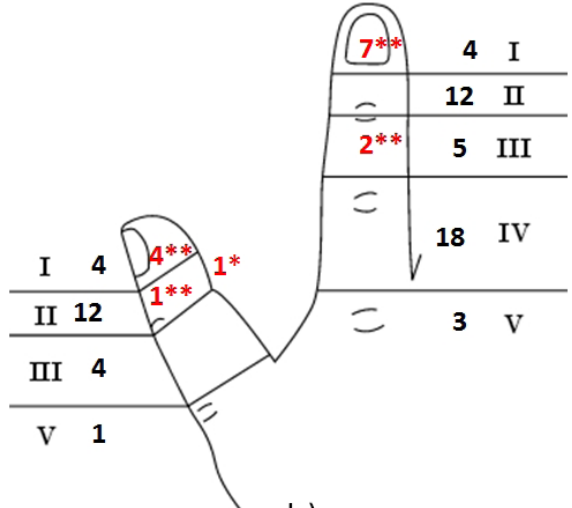

b)

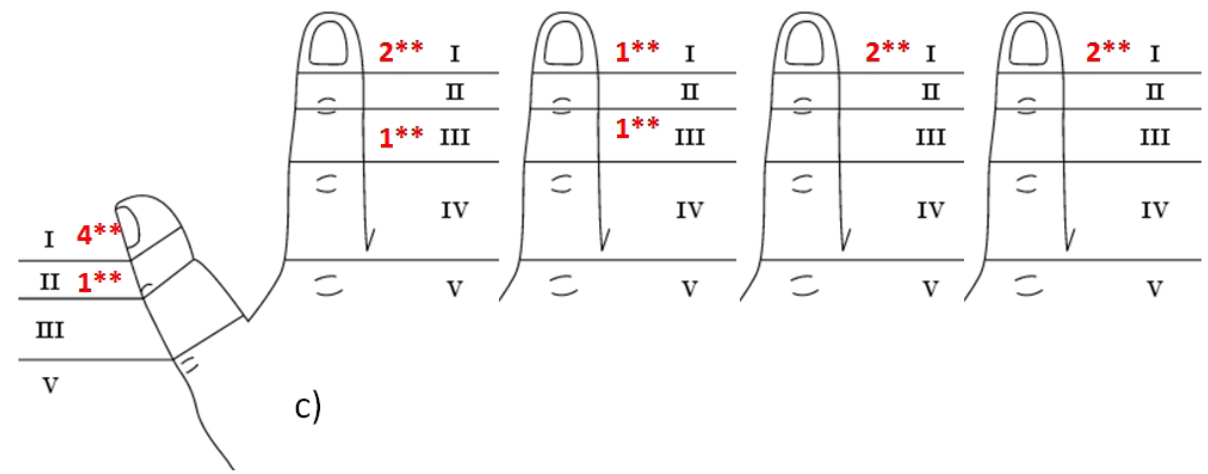

4. ábra Amputációs sérülések egy ujj amputációban Tamai osztályozása szerint (78 beteg) a) Sérüléses amputációk szintje a hüvelykujjon és a hosszú ujjakon (II-V)

b) A mütéti amputációk (63), revaszkularizáció* (1) és rekonstrukciók** (14), szintje a hüvelykujjon és a hosszú ujjakon (II-V)

c) A rekonstrukciók** (14) megoszlása az egyes ujjakon 

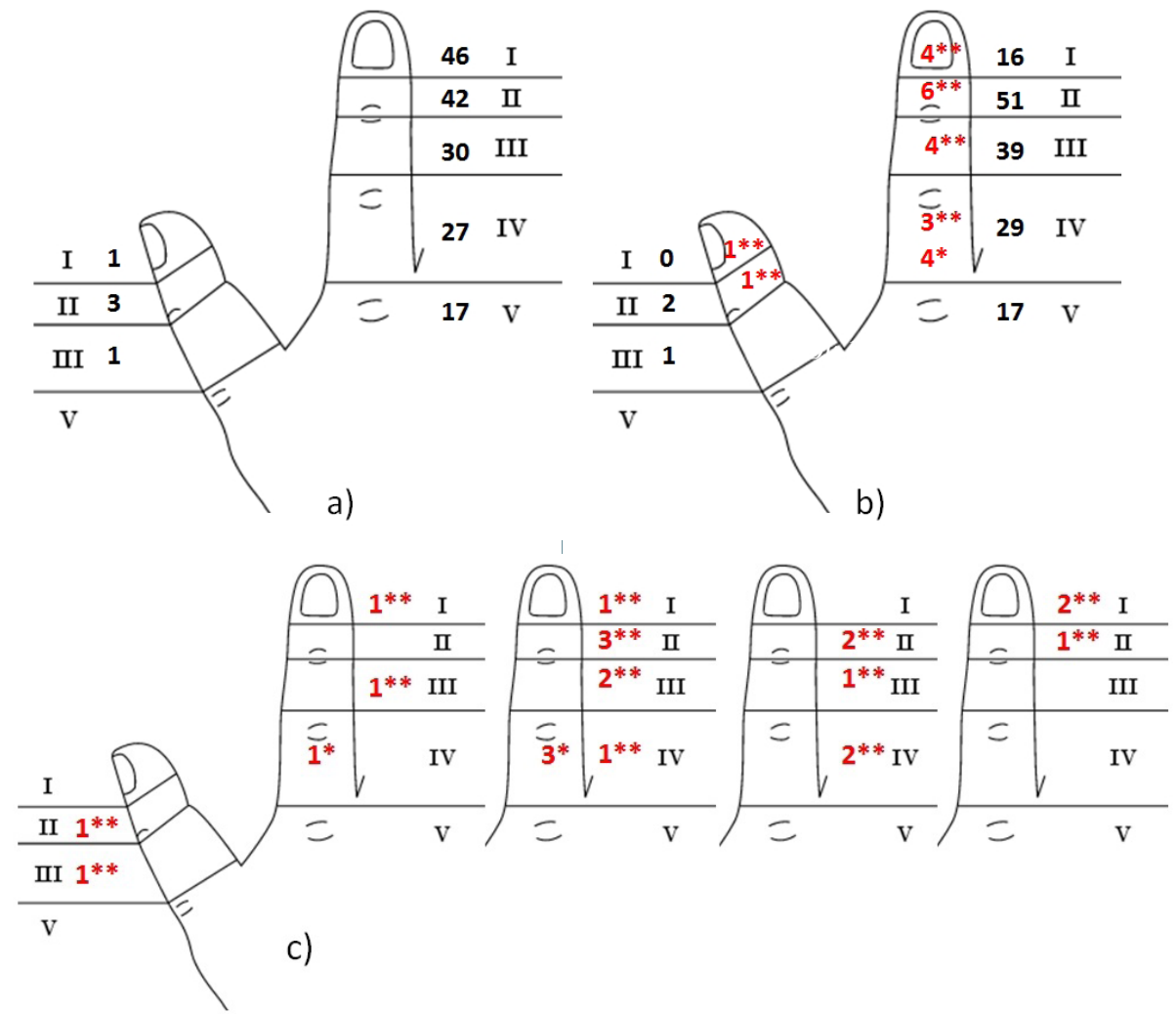

5. ábra Amputációs sérülések több ujj amputációban Tamai osztályozása szerint a) Sérüléses amputációk (167) szintje a hüvelykujjon és a hosszú ujjakon (II-V)

b) A mütéti amputációk (144) a revaszkularizációk* (4) és a rekonstrukciók** (19) szintje a hüvelykujjon és a hosszú ujjakon (II-V)

c) A revaszkularizációk* (4), és a rekonstrukciók** (19) megoszlása az egyes ujjakon

\begin{tabular}{|c|c|c|c|c|c|c|}
\hline & $\begin{array}{c}78 \text { beteg } \\
\left(79-1^{+}\right)\end{array}$ & $\begin{array}{c}\text { primer } \\
\text { amputáció }\end{array}$ & $\begin{array}{l}\text { szekunder } \\
\text { amputáció }\end{array}$ & replantáció & revaszk.* & rekonstr.** \\
\hline totalis & 21 & 19 & $\begin{array}{c}2 \\
(2)\end{array}$ & $\begin{array}{c}0 \\
(2-2)\end{array}$ & & \\
\hline subtotalis & 43 & 28 & $\begin{array}{c}4 \\
\left(1+1^{*}+2^{* *}\right)\end{array}$ & $\begin{array}{c}0 \\
(1-1)\end{array}$ & $\begin{array}{c}1^{*} \\
\left(2^{*}-1^{*}\right)\end{array}$ & $\begin{array}{c}10^{* *} \\
\left(12^{* *}-2^{* *}\right)\end{array}$ \\
\hline $\begin{array}{l}\text { roncsolt } \\
\text { lágyrész/ } \\
\text { nyílt törés }\end{array}$ & $\begin{array}{c}14 \\
\left(15-1^{+}\right)\end{array}$ & 7 & $\begin{array}{c}3 \\
\left(1^{*}+2^{* *}\right)\end{array}$ & & $\begin{array}{c}0 \\
\left(1^{*}-1^{*}\right)\end{array}$ & $\begin{array}{c}4^{* *} \\
\left(6^{* *}-2^{* *}\right)\end{array}$ \\
\hline eredményes & & \multirow{2}{*}{54} & \multirow{2}{*}{9} & 0 & $1^{*}$ & $14^{*}$ \\
\hline sikertelen & & & & $(3-3)$ & $\left(3^{*}-2 *\right)$ & $(18 * *-4 * *)$ \\
\hline Összesen & 78 & \multicolumn{2}{|c|}{63 (81\%) } & 0 & $1 *(1 \%)$ & $14 * *(18 \%)$ \\
\hline
\end{tabular}




\begin{tabular}{|c|c|c|c|c|c|c|c|c|}
\hline & $\begin{array}{c}2009 . \\
\text { 06. 01-től }\end{array}$ & 2010. & 2011 & 2012 & 2013 & $\begin{array}{c}2014 . \\
06.01-i g\end{array}$ & $\begin{array}{c}\text { Betegek } \\
\text { száma }\end{array}$ & $\begin{array}{l}\text { Ujjak } \\
\text { száma }\end{array}$ \\
\hline I-II / I-III* & - & - & 1 & $1^{*}$ & - & - & 2 & 4 \\
\hline II-III & 3 & 8 & 3 & 4 & 3 & - & 21 & 42 \\
\hline III-IV / IV-V* & 3 & 5 & 3 & 2 & $\begin{array}{l}1+ \\
1 *\end{array}$ & - & 15 & 30 \\
\hline II-III-IV & 3 & 6 & 3 & - & 5 & 2 & 19 & 57 \\
\hline III-IV-V & 2 & 1 & 1 & 1 & - & - & 5 & 15 \\
\hline |-II-III-IV & - & - & 1 & 1 & - & - & 2 & 8 \\
\hline II-III-IV-V & 1 & 3 & 2 & - & 1 & - & 7 & 28 \\
\hline \multirow[t]{2}{*}{ I-II-III-IV-V } & - & - & 1 & - & - & - & 1 & 5 \\
\hline & & & & & & - & 72 & 189 \\
\hline
\end{tabular}

X. táblázat Amputációs sérülések mütéti ellátása több ujj amputációban (72 beteg). 2**\# ujjbegy visszavarrás gyermeknél

\begin{tabular}{|c|c|c|c|c|}
\hline 72 beteg & $\begin{array}{c}167 \mathrm{ujj} \\
(189-22)\end{array}$ & $\begin{array}{c}\text { primer } \\
\text { amputáció }\end{array}$ & revaszkularizáció* & rekonstrukció** \\
\hline totalis & 56 & 54 & $\mathbf{3}^{*}$ & $12^{* *}$ \\
\hline subtotalis & 74 & 59 & $1^{*}$ & $5^{* *}$ \\
\hline $\begin{array}{c}\text { roncsolt lágyrész/ } \\
\text { nyílt törés }\end{array}$ & 37 & 31 & $4^{*}$ & $19 * *$ \\
\hline Összesen & 167 & 144 & & \\
\hline
\end{tabular}

\begin{tabular}{|c|c|c|c|c|c|c|}
\hline \multicolumn{7}{|c|}{ XI. a táblázat Replantációk } \\
\hline & $\begin{array}{l}\text { Beteg neme, } \\
\text { életkora }\end{array}$ & $\begin{array}{c}\text { Sérülés } \\
\text { oka }\end{array}$ & $\begin{array}{l}\text { Sérült ujj, } \\
\text { végtag }\end{array}$ & $\begin{array}{l}\text { Sérülés } \\
\text { szintje }\end{array}$ & Eredmény & $\begin{array}{l}\text { Amputáció } \\
\text { szintje }\end{array}$ \\
\hline 1. & 59 éves férfi & körfürész & $\begin{array}{c}\text { bal } \\
\text { hüvelykujj }\end{array}$ & Tamai III & sikertelen & Tamai V \\
\hline 2. & 10 éves fiú & balta & bal kisujj & Tamai III & sikertelen & $\begin{array}{l}\text { Tamai III } \\
\text { rövidítéssel }\end{array}$ \\
\hline 3. & 4 éves lány & balta & $\begin{array}{c}\text { jobb } \\
\text { középsőujj }\end{array}$ & Tamai III & sikertelen & Tamai IV \\
\hline 4. & 13 éves lány & autó utas & bal felkar & $\begin{array}{l}\text { proximalis } \\
\text { harmad }\end{array}$ & sikertelen & $\begin{array}{c}\text { bal váll } \\
\text { exarticulatio }\end{array}$ \\
\hline
\end{tabular}




\begin{tabular}{|c|c|c|c|c|c|c|}
\hline \multicolumn{7}{|c|}{ XI. b táblázat Revaszkularizációk } \\
\hline & $\begin{array}{c}\text { Beteg } \\
\text { neme, } \\
\text { életkora }\end{array}$ & Sérülés oka & Sérült ujj & $\begin{array}{l}\text { Sérülés } \\
\text { szintje }\end{array}$ & Eredmény & $\begin{array}{c}\text { Amputáció } \\
\text { szintje }\end{array}$ \\
\hline 1. & 52 éves férfi & körfürész & $\begin{array}{c}\text { bal } \\
\text { mutatóujj }\end{array}$ & Tamai IV & sikeres & \multirow{5}{*}{$2015.058 .0001 .($} \\
\hline 2. & 52 éves férfi & flex & $\begin{array}{c}\text { bal } \\
\text { középsőujj }\end{array}$ & Tamai IV & sikeres & \\
\hline 3. & 64 éves férfi & körfürész & $\begin{array}{c}\text { bal } \\
\text { hüvelykujj }\end{array}$ & Tamai II & $\begin{array}{l}\text { 10.21755/MTO } \\
\text { sikeres }\end{array}$ & \\
\hline 4. & 66 éves férfi & körfürész & $\begin{array}{c}\text { jobb } \\
\text { középsőujj }\end{array}$ & Tamai IV & sikeres & \\
\hline 5. & 43 éves nő & balta & $\begin{array}{c}\text { jobb } \\
\text { középső ujj }\end{array}$ & Tamai IV & sikeres & \\
\hline 6. & 6 éves fiú & kalapács & $\begin{array}{c}\text { bal } \\
\text { középső ujj }\end{array}$ & Tamai I & sikertelen & Tamai II \\
\hline 7. & 50 éves nő & $\begin{array}{l}\text { karnison } \\
\text { fennakadt }\end{array}$ & $\begin{array}{c}\text { jobb } \\
\text { gyürűs ujj }\end{array}$ & Tamai III & sikertelen & Tamai IV \\
\hline
\end{tabular}

\section{Makro-amputációk mütéti ellátása}

Egy sérültre liftszerelés közben rázuhant a lift, hárman közlekedési balesetben sérültek. Egy motorkerékpár vezetőként frontálisan ütközött polytraumatizált (ISS 36), 2 sérült autó utasa volt.

A 68 éves román állampolgár férfi sérültet, akire a lift rázuhant, munkatársa a saját autójában szállította be, sokkos állapotban. Testének jobb oldala sérült, összeroncsolódott jobb alsó végtagján a femur középső harmadában amputációt végeztek, ezzel párhuzamosan másik team átvizsgálta az összeroncsolódott könyökízületet, s bár az alkar distalis 2/3-a és a kéz nem sérült, a beteg általános állapota, alapbetegsége (kezeletlen hypertonia), és életkora miatt a humerus distalis harmadában amputálták a végtagot. 13 napos kórházi ápolásból 2 napot töltött az intenzív osztályon. Külföldi otthonába bocsátását követő utókezeléséről, esetleges jobb alsó és felső végtag protetizálásáról nincs információnk.

A polytraumatizált (agy, mellkas, alsó végtag, felső végtag), 39 éves sérültnél (a baleset 39. születésnapján történt!) a felkar amputációjára az arteria brachialisból feltételezett erős vérzés miatt, életmentő céllal került sor.
Látását agysérülése következtében elvesztette. 33 napot töltött az intenzív osztályon, már 1 hónappal az amputáció után „fantomérzése” volt, majd 15 hétig ápolták az alsó végtag sérüléseinek szövődménye miatt szeptikus osztáIyon. Reaktív depresszió alakult ki, ami pszichiátriai kezelést igényelt, hosszú ideig rémálmok gyötörték. Alsó végtag ellenőrzése, utókezelése mai napig tart, háromlábú bottal teljes terheléssel jár. Felső végtagjára protézis nem készült.

A 42 éves autóutas férfi végtag csonkja, és a szabályosan beszállított amputátum ugyan alkalmas lett volna replantációra, de az anamnesisre tekintettel - gyermekkorában motor elgázolta, polytraumatizált volt, az egyik veséjét eltávolították, továbbá néhány hónappal e baleset előtt myocardialis infarktusa volt - az amputáció befejezésére került sor. További kezelésre, protetizálásra OORI-ba irányítva.

A 13 éves autóutas lány sikertelen felkar replantációja után - életet veszélyeztető vérzés miatt - vállízületi exarticulatio történt. Pszichésen rendezett, a ma elérhető legkorszerübb felső végtag protézis készítése - Bécsben - folyamatban van (XII. táblázat). 


\begin{tabular}{|c|c|c|c|c|c|}
\hline \multicolumn{6}{|c|}{ XII. táblázat Makro-amputációk mútéti ellátása } \\
\hline év & beteg & oldal & sérülés szintje & $\begin{array}{l}\text { amputáció } \\
\text { szintje }\end{array}$ & $\begin{array}{c}\text { protézis, } \\
\text { vagy helyre- } \\
\text { állító mútét }\end{array}$ \\
\hline 2012 & $\begin{array}{c}68 \text { éves férfi } \\
\text { liftszerelés köz- } \\
\text { ben a lift rázuhant } \\
\text { multitrauma }\end{array}$ & jobb & $\begin{array}{l}\text { könyökízület IV } \\
\text { fokban nyílt törése }\end{array}$ & $\begin{array}{c}\text { felkar distalis } \\
\text { harmada }\end{array}$ & - \\
\hline 2012 & $\begin{array}{l}42 \text { éves férfi } \\
\text { autó utas }\end{array}$ & bal & radiocarpalis ízület & $\begin{array}{l}\text { alkar distalis } \\
\text { harmadában }\end{array}$ & $\begin{array}{l}\text { OORI-ban } \\
\text { protézis }\end{array}$ \\
\hline 2013 & $\begin{array}{l}39 \text { éves férfi mo- } \\
\text { torkerékpár vezető } \\
\text { polytrauma ISS } 36\end{array}$ & bal & $\begin{array}{l}\text { humerus distalis vég, } \\
\text { könyök II } \\
\text { fokban nyílt } \\
\text { törése, erős vérzés az } \\
\text { a. brachialisból }\end{array}$ & $\begin{array}{c}\text { felkar } \\
\text { középső } \\
\text { harmadában }\end{array}$ & - \\
\hline 2014 & $\begin{array}{l}13 \text { éves lány } \\
\text { autó utas }\end{array}$ & bal & $\begin{array}{l}\text { felkar replantáció } \\
\text { után ismételten } \\
\text { posztoperatív vérzés } \\
\text { az a. brachialisból }\end{array}$ & $\begin{array}{c}\text { vállízületi } \\
\text { exarticulatio }\end{array}$ & $\begin{array}{l}\text { Bécsben } \\
\text { protézis } \\
\text { készítése } \\
\text { folyamat- } \\
\text { ban }\end{array}$ \\
\hline
\end{tabular}

XIII. táblázat Az amputációt végző orvosok szakvizsga képesítése

\begin{tabular}{|c|c|c|c|c|c|}
\hline & \multicolumn{2}{|c|}{ orvosok száma } & \multicolumn{2}{|c|}{ végzett mútétek száma } & asszisztens \\
\hline $\begin{array}{l}\text { Kézsebész szakorvos } \\
\text { Kéz- és Mikrosebészeti Osztályról } \\
\text { Mozgásszervi Osztályról } \\
\text { Külső intézményből }\end{array}$ & $\begin{array}{l}4 \\
7 \\
2\end{array}$ & $36,1 \%$ & $\begin{array}{c}20(13 \%) \\
52(34 \%) \\
6(4 \%)\end{array}$ & $51 \%$ & \multirow[t]{2}{*}{$\begin{array}{c}16 / 98 \\
16 \%\end{array}$} \\
\hline Baleseti sebész szakorvos & $\begin{array}{c}6 \\
16,7 \%\end{array}$ & \multirow{2}{*}{$63,9 \%$} & $20(13 \%)$ & \multirow{2}{*}{$49 \%$} & \\
\hline $\begin{array}{l}\text { Nem szakorvos / } \\
\text { rezidens }\end{array}$ & $\begin{array}{c}17 \\
47,2 \%\end{array}$ & & $56(36 \%)$ & & $\begin{array}{c}13 / 56 \\
23 \%\end{array}$ \\
\hline Összesen & \multicolumn{2}{|c|}{36 orvos } & \multicolumn{2}{|c|}{154 mútét } & $\begin{array}{c}29 / 154 \\
19 \%\end{array}$ \\
\hline
\end{tabular}

\section{Az amputációs sérülést ellátó orvosok szakvizsga képesítése}

Az ellátó orvosok 63,9\%-a nem kézsebész szakorvos, ugyanakkor ők végezték a mútétek közel felét (49\%). Ezen belül 47,2\% rezidens orvos, akik a mútétek 36\%-át végezték. Figyelemre méltónak tartjuk, hogy a mútétekhez átlagosan 19\%-ban segítette az operáló orvost asszisztens, és a rezidensek is csupán a mútétek 23\%-ában kaptak segítő asszisztenst!!! (XIII. táblázat).

\section{Ápolási napok száma}

Két beteg ujjbegy amputáció befejezése ambulánsan történt, egy polytraumatizált sérült csupán 11 órát élt ( 0 nap/3 beteg). $A$ betegek 86\%-a 5 napon belül távozott, ezen belül $32 \%$ a második napon (6. ábra). 


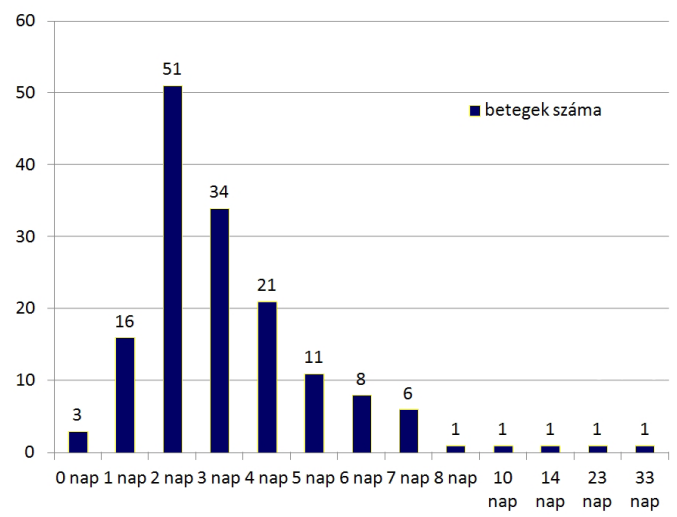

6. ábra Ápolási napok száma

\section{Irodalmi összehasonlítás}

Az utolsó 5 év irodalmi számadatai nagyságrendekkel több replantációról szólnak, mint azt a saját anyagunkban találtuk (1, 11-13, 24, $33,34)$. Hazai publikációk fóleg a '80-as '90-es években jelentek meg $(8-10,15,19,20,21$, 25-29).

Renner A., Manninger J., Sántha A. (26), és Sántha A., Renner A. (28) már 1981-ben évtizedekkel megelőzve a külföldi gyakorlatot végperc sikeres replantációját végezték. Sántha $E$. és munkatársai (29) fiatal sérült mindkét felső végtag amputációjában - a bal felkar proximalis fele és a válltájék roncsolódott, míg a könyöktől distalisan nem volt sérülés; a jobb kéz és az alkar szintén roncsolódott, viszont a felkar és a könyöktájék nem sérült - legalább egy végtag megmentésére a bal kéz és alkar átültetését végezték a jobb felkar csonkjára. Az utolsó hazai közlemény (14) 20 évvel ezelőtt (!), 1994-ben jelent meg. A 2006-ban e témához kapcsolható egyetlen közlemény már a replantációk finanszírozási aspektusával foglalkozott (31).

Fufa és munkatársai (6) 3 év alatt 135 replantációt végeztek, s ezek 69\%-a volt sikeres. Gonser és munkatársai (7) 3 év alatt 2010-2012 között 53 amputációs sérülésből 18 amputációt és 35 replantációt végeztek, 28 betegnél hüvelykujjon, 7 betegnél hüvelykujjon és valamelyik hosszúujjon.

Berlin és munkatársai (3) gyűjtött anyagot dolgoztak fel az USA több kórházát bevonva. 13 év alatt 1999-2011 között 3010 betegen 14875 ujj replantációját végezték, 2555 felnőtt és 455 gyermek volt. A sikerességi arányuk $81,5 \%$.
Friedrich és munkatársai (5) szintén az USA több kórházát bevonva, 2001, 2004, 2007 éves adatainak összességét dolgozták fel. 9407 amputációs sérülésből 1361 replantációt végeztek. A replantációk aránya oktató kórházban 19\%, nem oktató kórházban 7\% volt. Megállapították továbbá, hogy magasabb a replantációk száma centrumokban, városi kórházakban, míg alacsonyabb ott, ahol a beteg saját maga fizeti a kezelést, vagy a biztosítással nem rendelkező beteg segélykórházban kap ellátást.

Shale és munkatársai (32) az USA National Trauma Data Bank adatainak feldolgozásával kizárólag a hüvelykujj amputációs sérüléseinek kezelését vizsgálta. 2007 és 2010 között 3341 hüvelykujj amputációs sérülés közül 550 ujjon (16,5\%) végeztek replantációt, amelyek 84,9\%-a sikeres volt. Oktató kórházban 2103 sérült került, és 427 (20,3\%) replantációt végeztek $86,2 \%$-os sikerességgel. Nem oktató kórházban 1238 sérültet kezeltek, és 123 $(9,9 \%)$ replantációt végeztek, $80,5 \%$-os sikerességgel. Elemzésükből kiderült, hogy a nagyobb központokban 3,4-szer gyakoribb a megkísérelt replantáció, mint a kisebb betegforgalmú kórházakban, és a nagy betegforgalmú oktató kórházakban az elvégzett replantációk sikerességi rátája is magasabb a nagyobb gyakorlottság révén.

Larson és munkatársai (16) 11 év alatt 62 felső végtag (radiocarpalis ízülettől proximalis) amputációs sérültnél végeztek 20 esetben makro-replantációt, amelyek 70\%-a sikeres volt. Az elveszített 6 végtag minden esetben polytraumatizált (ISS>16) sérültnél volt.

Marques és munkatársai (17) szerint felső 
végtag amputációban a gold standard a replantáció. Még kétoldali felső végtag replantáció is jó eredményű lehet. A bemutatott 21 éves nőbeteg 16 hónappal a két felső végtagjának replantációja után eredeti titkárnői munkakörében dolgozik, a jobb kéz funkciójával nagyon elégedett, a bal kéz funkciójával elégedett. Fontosnak tartják a szakképzés, a szervezés, és a finanszírozás javítását, mert mindenütt veszteséges a replantáció $(2,7,18,23,30,31)$.

\section{MEGBESZÉLÉS}

Az igen jelentős számú amputációs kézsérülés retrospektiv elemzése kevésbé a sérültek, sokkal inkább az egészségügyi intézmény finanszírozása szempontjából mutat kedvezőbb képet. Az esetek több mint 2/3-ában az elvégzett mútét már az első ellátás során a definitív amputáció volt, választott helyen, zömében rövidítéssel, amelyet a Tamai osztályozás szerinti besorolás is igazol. Az erre való törekvést mutatja a hosszú várakozás után is elvégezhető „rövid” mútétek magas száma, a finanszírozás szempontjából kedvezőbb rövid kórházi ápolási idő magas aránya. Az amputációk sérüléses és mútéti szintjének összehasonlításából egyértelműen kiderül, hogy a „gyors” definitív ellátás érdekében legtöbbször - lágyrész nyerési céllal - a szükségesnél proximalisabb szinten történik a csonkolás befejezése, holott számos módszerrel az eredeti amputációs szinten megtartható lenne a csonk hossza. Olyan esettel is találkoztunk az anyagban, ahol a mútéti leírás szövege szerint az epiphysis fúgát azért távolították el a gyermek hüvelykujján, hogy „palmar felől jó bőrrel lehessen fedni a csonkot"!!

Minden igényesebb beavatkozás, a hosszmegtartó amputáció befejezés, revaszkularizáció, replantáció hosszabb mútéti időt, hosszabb kórházi tartózkodást jelent. Komolyabb megterhelés az ügyeleti csapatnak, a mútétet végző teamnek, mikroszkóp használatában jártas operatőr szükséges. Magasabb költség a kórháznak, hosszabb ápolás, hosszú, szakszerű utókezelés szükséges, amit ezen beavatkozások OEP finanszírozása nem fedezne. $\mathrm{Az}$ irodalom áttekintése során azonban azt is láttuk, hogy a replantációk sehol nem nyereségesek, sem Európában, sem a tengeren túli országokban. Németországban egy hüvelykujj replantáción 831,- Euro, egy hüvelykujj és egy hosszú ujj együttes replantációján 263,- Euro vesztesége, míg egy hüvelykujj amputáción 72,- Euro nyeresége van a Kórháznak. A probléma megoldását azonban nem a replantációk számának csökkentésében, és a definitív primer csonkolások számának növelésében látják, hanem következtetésük, és sebészi gyakorlatuk a beteg számára kedvezőbb megoldás, a végtag/végtagrész megtartását célzó mútét. Emellett minden: fórumon küüdenek a finan! szírozás javításáért, mert véleményük szerint a társadalom a gazdasági problémák megoldását nem terhelheti rá az egészségügyre, nem kompenzálhatja az elégtelen finanszírozáson keresztül, és nem helyezheti a döntés felelősségét az orvosok vállára.

A retrospektív elemzés során tapasztalt ellátási gyakorlat - az ujjak rövidítésével végzett amputáció befejezések, ugyanakkor igen kisszámú replantáció - okait keresve, azt részben az ügyeleti rendszerben, az elégtelen kézsebész szakorvosi létszámban, részben a rezidensek elégtelen felkészítésében, magukra hagyatottságukban, s részben a mikrosebészeti technika ismeretének és a gyakorlati alkalmazásának hiányosságaiban véltük megtalálni.

\section{KÖVETKEZTETÉS}

$A z$ egészségügyben végbemenő, immár két évtizede zajló „reformok” (ágyszám és létszámcsökkentés, ugyanakkor múszakosított munkarend, a finanszírozási szempontok előtérbe helyezése) következményei a sérültellátás minőségének negatív változásában már számadatokkal igazolhatóan megmutatkoznak.

Jól látható, hogy az intézményi finanszírozás szempontjából az amputáció a nyereséges beavatkozás, az ellátó orvosnak ez a relatíve egyszerü, rövid mútét, ügyeletben a speciális felkészültséggel még nem rendelkező rezidensre is rábízzák, mert alacsony a mútéti rizikó, a szövődmény lehetősége, továbbá rövid a beteg kórházi ápolása. De valóban az amputáció a „jó mútét" ??? Vajon az amputációs sérültek hány százaléka válik „lelki beteggé” és szorul pszichológiai kezelésre $(4,22)$ ?

\section{Javaslataink}

Az amputációs sérülések ellátásakor is mindenekelőtt a „beteg üdve” legyen az ellátó 
orvos vezérgondolata, vagyis egy adott korszak legjobb kezelési módszerét kell alkalmaznunk, és ez nem biztos, hogy mindig a legegyszerübb, legkényelmesebb eljárás. Súlyos roncsolásos kézsérülésekben az amputáció az utolsó megoldás legyen, s ne a primeren elsőként választott módszer!

A rezidens orvosokat ne kötelezzék - még létszám hiányra hivatkozva sem - egyedül, megfelelő jártasságú asszisztensi segítség nélküli amputációs mútét végzésére. Valamennyi fiatal orvosnak el kellene sajátítani a csonkolással kapcsolatos elméleti és gyakorlati ismereteket, mielőtt még önállóan ilyen mútétet végez. Legyen kórházon belül szervezett, rendszeres, tematikus elméleti és gyakorlati oktatás a rezidensek számára, munkába állásuk pillanatától kezdve.

Ismét lehetővé kellene tenni a mikrosebészet nehéz, de gyönyörű feladatának ellátására is alkalmas kollégák képzését, akik mind az operációs mikroszkóp, mind a mikrosebészeti technika műszereit ismerik és használni, alka!mązni tuciják, aikik támogatási kapnának a revaszkularizációk és a replantációk elvégzésére, valamint az érnyeles szövetpótlásokra is.

\section{IRODALOM}

1. Adani R., Pataia E., Tarallo L., Mugnai R.: Results of replantation of 33 ring avulsion amputations. J. Hand Surg. Am. 2013. 38. (5): 947-956.

2. Barbary S., Dap F., Dautel G.: Finger replantation: surgical technique and indications. Chir Main. 2013. 32. (6): $363-372$.

3. Berlin N. I.,Tuggle CT, Thomson J. G., Au A.: Digit replantation in children: a nationwide analysis of outcomes and trends of 455 pediatric patients. Hand, 2014. 9: 244-252.

4. Csillag l.: Amputációk lelki következményei. Orvosok Lapja, 1946. 2. (21): 1318-1319.

5. Friedrich J. B., Poppler L. H., Mack C. D., Rivara F. P., Levin L. S., Klein M. B.: Epidemiology of upper extremity replantation surgery in the United States. J. Hand Surg. Am. 2011. 36. (11): 1835-1840.

6. Fufa D., Calfee R., Wall L., Zeng W., Goldfarb C.: Digit replantation: experience of two U.S. Academic Level-I Trauma Centers. J. Bone Joint Surg. Am. 2013. 95. (23): 2127-2134.

7. Gonser P., Medved F., Schaller H. E., Lotter O.: Ökonomischer Profit von Fingerverletzungen in einem handchirurgischen Zentrum - Replantation vs. Amputation. Handchir. Mikrochir. Plast. Chir. 2013. 45: 350-353.

8. Gulyás G., Takács L., Kartik I.: Hüvelykujj visszavarrása mikrosebészeti technikával végzett ér- és idegvarrattal. Magy. Traumatol. Ortop. Helyreállító Seb. 1981. 24. (4): 274-278.

9. Gulyás G., Réffy A., Józsa L., Renner A.: Experimental microvascular sleeve anastomoses. Acta Chir. Hung. 1984. 25. (4): 209-218.

10. Hajdu I., Schwendenweinen E., Gatterer R., Vécsei V.: Az ujjbegy amputációs sérülésének visszavarrása. Magyar Traumatológia Ortopédia Kézsebészet Plasztikai Sebészet, 1998. 41. (2): 169-173.

11. Huang H. F., Yeong E. K.: Surgical treatment of distal digit amputation: success in distal digit replantation is not dependent on venous anastomosis. Plast. Reconstr. Surg. 2015. 135. (1): 174-178.

12. Jazayeri L., Klausner J. Q., Chang J.: Distal digital replantation. Plast. Reconstr. Surg. 2013. 132. (5): 1207-1217.

13. Jiang L. F., Zhou F. Y., Chi Z. L., Yu Q., Chu T. G., Gao W. Y.: Characteristics and replantation of degloving injury of distal finger. J. Orthop. Trauma, 2013. 26. (8): 637-639.

14. Józsa L., Réffy A., Renner A., Gyárfás F.: Izom és ínelváltozások replantált végtagokon. Magyar Traumatológia Ortopédia Kézsebészet Plasztikai Sebészet, 1994. 37. (5): 423-427.

15. Kubatov M., Nyárády J., Nemessányi Z.: Replantált ujjak vérkeringés vizsgálata gamma kamerával. Magy. Traumatol. Orthop. Helyreállitó Seb. 1987. 30. (2): 117-126.

16. Larson J. V., Kung T. A., Cederna P. S., Sears E. D., Urbanchek M. G., Langhals N. B.: Clinical factors associated with replantation after traumatic major upper extremity amputation. Plast. Reconstr. Surg. 2013. 132. (4): 911-919.

17. Marques M., Correia-Sá I., Festas M. J., Silva S, Silva A. I., Silva A., Amarante J.: Six years of follow-up after bilateral hand replantation. Chir. Main. 2013. 32. (4): 226-234.

18. Mehta K., Pierce P., Chiu D. T., Thanik V.: The effect of residency and fellowship type on hand surgery clinical practice patterns. Plast. Reconstr. Surg. 2015. 135. (1): 179-186.

19. Nyárády J., Vilmos Z., Kovácsy A.: Felsővégtag replantációk. Orv. Hetil. 1985. 126. (6): 313-316.

20. Nyárády J., Kubatov M., Vámhidy L.: Végtagreplantációk eredményei. Magy. Traumatol. Orthop. Helyreállító Seb. 1989. 32. (3): 211-219.

21. Nyárády J., Kubatov M., Péley I., Gazsó I.: Ujjreplantációk. Magy. Traumatol. Orthop. Helyreállító Seb. 1990. 33. (4): 261269.

22. Orsós J.: Amputáció és a rokkantság. Orvosképzés, 1934. 24. 132-136.

23. Peterson B. C., Mangiapani D., Kellogg R., Leversedge F. J.: Hand and microvascular replantation call availability study: a national real-time survey of Level-I and Level-II Trauma Centers. J. Bone Joint Surg. Am. 2012. 94. (24): e185.

24. Prucz R. B., Friedrich J. B.: Upper extremity replantation: current concepts. Plast. Reconstr. Surg. 2014. 133. (2): $333-342$. 
25. Renner A.: Mikroszkópos sebészet. Magy. Traumatol. Orthop. Helyreállító Seb. 1979. 22. (3-4): 188-190.

26. Renner A., Manninger J., Sántha A.: Amputált ujjak replantációja. Orv. Hetil. 1981. 122. (40): 2455-2457.

27. Renner A.: A hazai kézsebészet fejlödése. Magy. Traumatol. Orthop. Helyreállító Seb. 1983. 26. (4): $243-246$.

28. Sántha A., Renner A.: Amputált ujjak replantációja Orv. Hetil. 1981. 122. (40): 2459-2460.

29. Sántha E., Szarvas J., Varga Gy., Varga M.: Felsővégtag átültetése az ellenoldali felkarcsonkra. Magy. Traumatol. Orthop. Helyreállitó Seb. 1989. 32. (1): 1-7.

30. Sears E. D., Shin R., Prosser L. A., Chung K. C.: Economic analysis of revision amputation and replantation treatment of finger amputation injuries. Plast. Reconstr. Surg. 2014. 133. (4): 827-840.

31. Sebestyén A., Boncz I., Dózsa Cs., Tóth F., Vámhidy L.: Replantációk finanszírozási aspektusból. Magyar Traumatológia Ortopédia Kézsebészet Plasztikai Sebészet, 2006. 49. (1): 47-56.

32. Shale C. M., Tidwell J. E. 3rd, Mulligan R. P., Jupiter D. C., Mahabir R. C.: A nationwide revieu' of the treatment patterns of traumatic thumb amputations. Ann. Plast. Surg. 2013. 70. (6): 647-651.

33. Venkatramani H., Raja Sabapathy S.: Fingertip replantation: Technical considerations and outcome analysis of 24 consecutive fingertip replantations. Indian J. Plast. Surg. 2011. 44. (2): 237-245.

34. Wang X., Zhang W. K., Yin S. M., Wang H. B., He T., Gong Y. Q., Zhu G. M., Mao G. L., Hu M. S., Li J.: Fingertip replantation with anastomosis of palm vein and retaining nail. J. Orthop. Trauma, 2013. 26. (8): 639-641

Prof. Emer. Dr. Renner Antal

Péterfy Kórház Baleseti Központ

1081 Budapest, Fiumei út 17. 